\title{
The 5' Noncoding Region of Grapevine Chrome Mosaic Nepovirus RNA-2 Triggers a Necrotic Response on Three Nicotiana spp.
}

\author{
Isabelle Fernandez, Thierry Candresse, Olivier Le Gall, and Jean Dunez \\ INRA, Station de Pathologie Végétale, BP 81, 33883 Villenave d'Ornon Cedex, France \\ Accepted 9 December 1998.
}

\begin{abstract}
The $5^{\prime}$ noncoding region (NCR) of grapevine chrome mosaic nepovirus (GCMV) was cloned in a viral vector derived from potato virus $\mathrm{X}(\mathrm{PVX})$. The recombinant virus obtained was inoculated to Nicotiana benthamiana, $N$. clevelandii, and $N$. tabacum plants. Infected plants developed necrotic symptoms in place of the vein clearing and mosaic typically observed after inoculation with PVX. Northern (RNA) blot analysis showed that the replication of PVX was not specifically altered by the presence of the GCMV 5' NCR. Inoculation of recombinant PVX harboring deleted forms of the GCMV $5^{\prime}$ NCR showed that the three stem-loop structures at the $3^{\prime}$ end of the $5^{\prime}$ NCR (nucleotides 153 to 206) are dispensable for the induction of necrosis. Further deletion analysis indicated that neither the $5^{\prime}$-most 70 nucleotides of the $5^{\prime}$ NCR nor the downstream region (nucleotides 71 to 217 ) alone is able to induce the necrotic symptoms. In the presence of both the sequence encoding the GCMV coat protein and the GCMV 3' NCR, the GCMV $5^{\prime}$ NCR failed to induce necrosis in the PVX background. The mechanisms by which the expression of the $5^{\prime}$ NCR might modify PVX symptoms are discussed.
\end{abstract}

Plant viruses can induce a wide range of symptoms in their hosts, the most common ones being chlorosis and necrosis (Culver et al. 1991). Symptom appearance results from a complex interaction between the virus and the plant, involving both viral and plant determinants. Recent advances in recombinant DNA technologies have allowed the identification of several viral determinants involved in symptomatology. Because they are easily identifiable and often associated with plant resistance to infection, necrotic reactions, especially of the hypersensitive response (HR) type, remain the most thoroughly studied. The different studies have shown that, generally, no link between symptoms and a given viral protein can be drawn and that coding as well as noncoding regions have the potential to modulate symptom expression. For example, an $\mathrm{HR}$ is elicited by the coat protein (CP) of tobacco mosaic virus (TMV) in Nicotiana sylvestris plants carrying the $N^{\prime}$ gene (Saito et al. 1987), or the CP of potato virus X (PVX) in potato plants that have the $N x$ gene (Kavanagh et al. 1992;

Corresponding author: Olivier Le Gall; Telephone: (33) 05568432 05; Fax: (33) 05568432 22; E-mail: legall@ bordeaux.inra.fr
Santa Cruz and Baulcombe 1993), by the replicase gene of TMV in $N$. tabacum plants containing the $N$ gene (Padgett and Beachy 1993) and by the movement protein gene of tomato mosaic virus in tomato plants harboring the $T m-2$ or $T m-2^{2}$ gene (Meshi et al. 1989; Calder and Palukaitis 1992). In other cases, the plant gene(s) involved in the necrotic response (HR or otherwise) have not yet been identified. However, some viral determinants have been characterized. These include the product of gene VI of cauliflower mosaic virus (Schoelz et al. 1986), the $N$ gene of beet necrotic yellow vein virus (Jupin et al. 1992), the CP gene of alfalfa mosaic virus (AlMV; Neeleman et al. 1991), the $p 19$ and $p 22$ genes of tomato bushy stunt virus (Scholthof et al. 1995), the polymerase gene of cucumber mosaic virus (CMV; Kim and Palukaitis 1997) and the 5'most 618 nucleotides of CMV RNA-3 (Zhang et al. 1994).

Grapevine chrome mosaic virus (GCMV) is a member of the nepovirus genus (Martelli et al. 1965; Martelli and Quacquarelli 1972), within the family Comoviridae (Mayo and Martelli 1993; Goldbach et al. 1995). In natural conditions, GCMV mostly infects grapevine but can be transmitted experimentally to several dicotyledonous species. N. tabacum plants (cv. Xanthi) inoculated with GCMV show symptomless replication or faint chlorotic ringspots on inoculated leaves whereas the apical leaves remain symptomless and virus free (Brault et al. 1993). GCMV infects $N$. benthamiana systemically without inducing symptoms but does not infect $N$. clevelandii.

The genome of GCMV is composed of two single-stranded mRNAs separately encapsidated in polyhedral particles. Both mRNAs have a covalently linked protein (VPg) at their $5^{\prime}$ ends (Mayo et al. 1982) and a poly(A) tail at their 3' ends (Mayo et al. 1979). Each mRNA encodes a polyprotein cleaved by a viral protease to give the mature viral proteins (Demangeat et al. 1991). Sequence comparison of the $5^{\prime}$ noncoding regions (5' NCRs) of RNA-1 and RNA-2, 215 and 217 nucleotides, respectively, showed $68 \%$ homology, whereas the $3^{\prime}$ NCRs of both RNAs are fully identical (Brault et al. 1989; Le Gall et al. 1995a). The structure predicted for the $5^{\prime}$ NCRs is a potential stem-loop structure at the $5^{\prime}$ terminus (nucleotides 1 to 18), followed by a pyrimidine-rich region (nucleotides 19 to 134) and three other potential stem-loop structures (nucleotides 135 to 217), with a loop apex conserved in sequence, located just upstream of the initiation codon (Fig. 1; Le Gall et al. 1995b). In vitro translation experiments showed that these stem-loop structures are not involved in translation efficiency (Brault 1990). However, because these structures 
are conserved in occurrence, number, sequence, and secondary structure among various nepoviruses and their two genomic RNAs (Le Gall et al. 1995b), they may play an important role in the viral infection cycle or in host/virus interactions.

Because no full-length infectious clones are available for GCMV, it was not possible to investigate the possible roles of GCMV 5' NCRs in planta via mutagenesis. For the same reason, no construction of recombinants with a related nepovirus, such as tomato black ring virus, was conceivable. Furthermore, these two strategies would not have allowed the study of a specific region independently of the rest of the viral genome. We thus chose to use a plant viral vector derived from PVX (Fig. 2A; Chapman et al. 1992) to express the GCMV 5' NCR, devoid of any other GCMV sequence, in plants. This PVX vector has already proved efficient for the study of different aspects of plant/pathogen interactions (Rommens et al. 1995; Hammond-Kosack et al. 1995; Scholthof et al. 1995; Culver 1996; Joosten et al. 1997). Although this system has been especially designed to transiently express foreign genes, it can also be used to study the properties of a foreign noncoding RNA sequence (Culver 1996).

In this study, we show that the GCMV RNA-2 5' NCR dramatically exacerbates the symptoms induced by PVX on $N$. benthamiana, $N$. clevelandii, and $N$. tabacum. Because the $5^{\prime}$ NCR had the same effect on three different Nicotiana spp., we suggest that it does not act as a host range determinant in this genus.

\section{RESULTS}

\section{Symptoms induced by PVX and PVX:5'NCR on $N$. benthamiana, $N$. clevelandii, and $N$. tabacum.}

The 5' NCR of GCMV RNA-2 (nucleotides 1 to 217) was cloned in the PVX vector (Fig. 2). In vitro transcripts from $\mathrm{pP} 2 \mathrm{C} 2 \mathrm{~S}$ (nonrecombinant vector) and $\mathrm{pP} 2 \mathrm{C} 2 \mathrm{~S}: 5^{\prime} \mathrm{NCR}$ were inoculated onto $N$. benthamiana or $N$. clevelandii plants. The transcripts from $\mathrm{pP} 2 \mathrm{C} 2 \mathrm{~S}: 5^{\prime} \mathrm{NCR}$ were inoculated onto a total of $16 \mathrm{~N}$. benthamiana and $35 \mathrm{~N}$. clevelandii plants in the course of four and nine independent assays, respectively. $N$. tabacum cv. Xanthi plants were inoculated with extracts from leaves infected with $N$. benthamiana or $N$. clevelandii because primary inoculation of $N$. tabacum with transcripts had proven inefficient in preliminary experiments, as also described by Scholthof et al. (1995).

$N$. benthamiana and $N$. clevelandii plants infected with PVX displayed a vein clearing on the first systemically in-

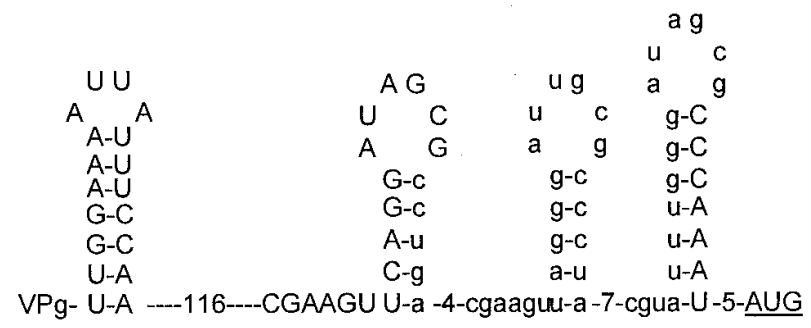

Fig. 1. Predicted secondary structure of the $5^{\prime}$ noncoding region (NCR) of grapevine chrome mosaic nepovirus (GCMV) RNA-2. Distances between hairpin structures are indicated in number of nucleotides. The sequence in small letters corresponds to the region deleted in $\mathrm{pP} 2 \mathrm{C} 2 \mathrm{~S}: 5^{\prime} \mathrm{NCR} \Delta$. The start codon is underlined. fected leaves, followed by a chlorotic mosaic on the upper leaves. The mosaic is accompanied by leaf-curling, more severe on $N$. benthamiana than on $N$. clevelandii. $N$. benthamiana or $N$. clevelandii plants inoculated with transcripts synthesized from pP2C2S:5'NCR showed necrotic symptoms (Fig. 3A, left). Although the necrosis reaction was systemic, the plants did not die and in some instances symptom recovery was eventually observed (Fig. 3A, left). Partial or total bleaching of $N$. benthamiana apical leaves was also sometimes observed with transcripts of pP2C2S:5'NCR, which was never noticed with nonrecombinant PVX (Fig. 3B, right). Furthermore, necrotic local lesions were occasionally observed on inoculated leaves of $N$. clevelandii infected by PVX containing the $5^{\prime}$ NCR of GCMV (data not shown). Such lesions were never visible on inoculated leaves of $N$. clevelandii infected with PVX.

In the present experimental conditions, $N$. tabacum infected with PVX displayed chlorotic spots that coalesced to give a chlorotic mosaic. Necrotic symptoms were sometimes superimposed on this mosaic. On N. tabacum plants, PVX:5'NCR induced necrotic spots (data not shown) on both inoculated and apical leaves. The necrotic spots were smaller in diameter than the chlorotic spots usually visible on tobacco infected with PVX and evolved toward necrotic ringspots. The symptoms observed were highly reproducible, since $100 \%$ of the plants infected with PVX:5'NCR displayed the necrotic symptoms described above.

As a control, a 252-bp EcoRV-SalI spacer DNA fragment from Escherichia coli (GenBank accession no. AE000464| ECAE000464, positions 1112 to 1364) was inserted into pP2C2S (Fig. 2B). The resulting virus, PVX:spacer, induced typical PVX symptoms on the three Nicotiana spp. (data not shown), demonstrating that the change in symptoms cannot be attributed solely to the introduction of an approximately 250bp DNA fragment in the PVX vector.

\section{Mapping of the GCMV sequence(s) involved in the necrotic response.}

To further delineate the sequences of the GCMV 5' NCR involved in the necrotic response, in vitro transcripts from $\mathrm{pP} 2 \mathrm{C} 2 \mathrm{~S}$ recombinants harboring deleted or mutated forms of this region were assayed on the same Nicotiana spp. The symptoms induced by a PVX vector containing a $5^{\prime}$ NCR with the HaeII fragment containing the repeated hairpins deleted (nucleotides 153 to 206; PVX:5'NCR $\Delta$, Fig. 2B) were almost as severe as those induced by PVX:5'NCR on the three Nicotiana spp. (Fig. 3C, top right). The severity of symptoms varied somewhat depending on the assay. On N. tabacum the spots first appeared chlorotic but rapidly turned necrotic and were smaller in diameter than the chlorotic spots induced by PVX (data not shown). Necrotic local lesions similar to those observed with PVX:5'NCR were occasionally visible on inoculated leaves of $N$. clevelandii. These observations suggest that the sequence deleted in PVX:5'NCR $\Delta$ may be marginally involved in but not fully responsible for the necrotic symptoms observed on PVX:5'NCR infected plants. The first 159 nucleotides of the GCMV $5^{\prime} \mathrm{NCR}$ are therefore sufficient to drastically change the symptoms induced by PVX from chlorotic to necrotic.

A deleted version of the GCMV $5^{\prime} \mathrm{NCR}$, lacking the first 70 nucleotides, was obtained and inserted into pP2C2S (Fig. 
2B). This plasmid was named pP2C2S:5'NCR 470 . N. clevelandii plants infected with PVX:5'NCR $\Delta 70$ displayed an attenuated mosaic (Fig. 3C, bottom left). Sap-inoculated $N$. tabacum also developed an attenuated mosaic both on inoculated and apical leaves (data not shown). These observations suggest that the first 70 nucleotides of the GCMV 5' NCR are required to trigger the necrotic response.

Considering the results obtained with PVX:5'NCR $\Delta$ and PVX: $5^{\prime} \mathrm{NCR} \Delta 70$, it was postulated that the stem loop located at the $5^{\prime}$ end of the NCR (nucleotides 1 to 18) by itself might be responsible for the necrotic response observed. To test this hypothesis, a pair of complementary oligonucleotides was de- signed to restore the stem loop (nucleotides 1 to 18) in $\mathrm{pP} 2 \mathrm{C} 2 \mathrm{~S}$ to give $\mathrm{pP} 2 \mathrm{C} 2 \mathrm{~S}$ :loop. In vitro transcripts from this plasmid were inoculated on $N$. clevelandii plants. Two weeks after inoculation, an attenuated mosaic was observed (data not shown). Such attenuated symptoms are frequently associated with infection by recombinant versions of PVX (Chapman et al. 1992). These results suggest that the first GCMV stem loop by itself is not able to induce the necrotic symptoms. The first 70 nucleotides, lacking in PVX:5'NCR $\Delta 70$, were cloned in pP2C2S to give pP2C2S:5'NCR70. Surprisingly, PVX: $5^{\prime} \mathrm{NCR} 70$ also failed to induce necrotic symptoms on $N$. clevelandii. Infected plants again showed an attenuated mo-

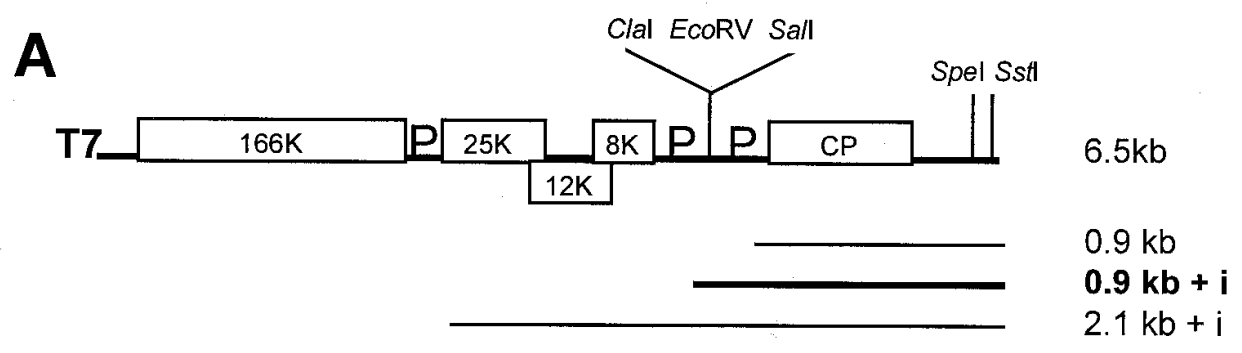

B

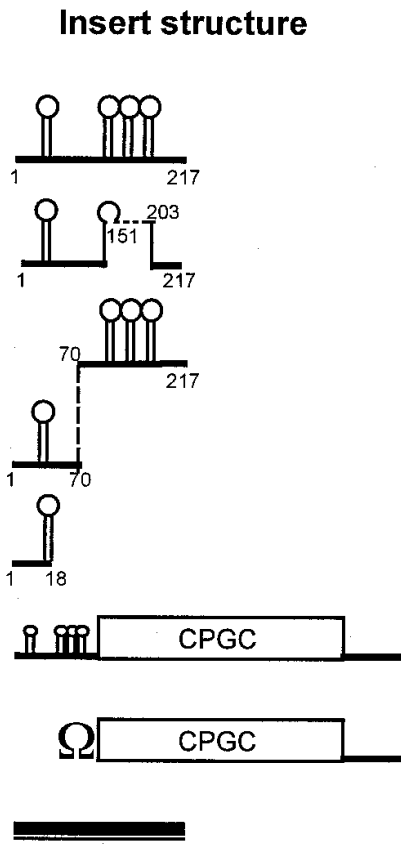

\section{Name of recombinant virus}

PVX:5'NCR

PVX:5'NCRA

PVX:5'NCR 70

PVX:5'NCR70

PVX:loop

PVX:5'CPGC3'

PVX: $\Omega$ CPGC3'

PVX:spacer
Insert size (nt)

$247 \quad(217)$

192 (159)

169 (147)

$70 \quad(70)$

$18(18)$

2066 (2036)

1916 (1886)

$252(252)$

\section{Necrosis on N. clevelandii}

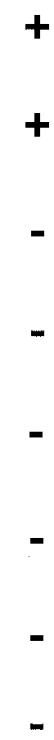

Fig. 2. A, Schematic representation of the potato virus $X(P V X)$ vector. Boxes represent the five open reading frames of the PVX genome and the molecular masses of their respective products are indicated, except for the coat protein ( $\mathrm{CP} ; 25 \mathrm{kDa})$. Size of the recombinant $\mathrm{PVX}$ derived from pP2C2S is indicated as well as the respective sizes of the subgenomic RNAs synthesized during replication. P: subgenomic RNA promoter. The CP promoter was duplicated to allow expression of the foreign gene following transcription of a new subgenomic RNA. A small polylinker was added between the duplicated promoters to allow cloning of foreign sequences (Chapman et al. 1992). T7: promoter for the RNA polymerase of the T7 bacteriophage. SpeI, Sst $\mathrm{I}$ : unique restriction sites introduced dowstream from the PVX sequence to allow linearization of the vector prior to in vitro transcription. i: size of the foreign sequence inserted, in number of bases. B, Schematic representation of inserts tested. Boxes represent coding regions; lines represent noncoding regions. Hairpins of grapevine chrome mosaic nepovirus (GCMV) $5^{\prime}$ noncoding region (NCR) are displayed. Numbers shown on insert structure give position of first and last nucleotides of the GCMV $5^{\prime} \mathrm{NCR}$ inserted into pP2C2S, as well as the region deleted for insert 5'NCR $\Delta$. Numbers in parentheses indicate size of the GCMV sequence within a given insert. The Escherichia coli DNA used in the PVX:spacer construct is indicated by a double line. 
saic (Fig. 3C, bottom right), slightly milder than the one visible on plants infected with PVX:5'NCR $\Delta 70$ (Fig. 3C, bottom left). Together, these results suggest that neither the $5^{\prime}$ terminal stem-loop structure nor the region of the $5^{\prime} \mathrm{NCR}$ missing in PVX: $5^{\prime} \mathrm{NCR} \Delta 70$ is sufficient to induce the necrotic reaction.

\section{Viral accumulation of the recombinant PVX vector.}

The results obtained with PVX:5'NCR were unexpected, as recombinant PVX vectors usually induce milder symptoms than nonrecombinant PVX (Chapman et al. 1992; HammondKosack et al. 1995; I. Fernandez, personal observations). To further investigate a possible effect of the GCMV $5^{\prime} \mathrm{NCR}$ on PVX replication or accumulation, Northern (RNA) blot hybridization analysis of infected plants was carried out.

Total RNAs were extracted from infected plants and a Northern blot hybridization analysis was performed with RNA probes complementary to either the PVX CP coding region or the GCMV 5' NCR. The recombinant virus PVX:5'NCR accumulated to levels approximately eight times lower than those of nonrecombinant PVX derived from $\mathrm{pP} 2 \mathrm{C} 2 \mathrm{~S}$. The ratio of subgenomic RNAs to each other was usually not significantly affected by the presence of the GCMV 5' NCR or 5' NCR $\Delta$ (Fig. 4). The virus PVX:spacer also accumulated to a level similar to that of $\mathrm{PVX}: 5^{\prime} \mathrm{NCR}$, confirming that the reduced accumulation is not specifically attributable to the presence of the GCMV $5^{\prime}$ NCR but is to be linked with the insertion of foreign sequences in the PVX genome (data not shown). This is consistent with the observations of Chapman et al. (1992), who showed that the insertion of a foreign sequence in PVX usually has a debilitating effect on virus accumulation. Furthermore, reverse transcription-polymerase chain reaction (RT-PCR) analysis indicated that no significant insert deletion had occurred in the PVX: $5^{\prime} \mathrm{NCR}$ progeny (data not shown), while such deletions are a common occurrence when propagating recombinant PVX (Chapman et al. 1992; Hammond-Kosack et al. 1995).

\section{The necrogenic effect of the GCMV $5^{\prime}$ NCR can be attenuated.}

In PVX:5'CPGC3', the 5' NCR of GCMV is followed by the sequence encoding the GCMV CP and by the GCMV $3^{\prime}$ NCR (Fig. 2B). N. benthamiana and $N$. clevelandii plants infected with this recombinant virus displayed a mild mosaic and N. tabacum showed highly attenuated PVX symptoms. The GCMV 5' NCR was therefore not able to induce necrotic symptoms in this new genomic context. However, one of the eight $N$. tabacum plants inoculated with PVX:5'CPGC3' displayed necrotic symptoms similar to those induced by PVX:5'NCR on two apical leaves (Fig. 3D). RT-PCR and sequence analysis of the virus content of this necrosis showed that the foreign sequence introduced into the PVX vector had been deleted down to a 270-bp region corresponding to the $5^{\prime}$ NCR and the first 33 nucleotides of the CP gene (data not shown). Furthermore, $N$. benthamiana inoculated with PVX: $\Omega$ CPGC3', where the $5^{\prime}$ NCR of GCMV had been replaced by the leader $\Omega$ of TMV, displayed mosaic symptoms similar to those of PVX:5'CPGC3'-infected plants. Taken together, these results show that the necrogenic effect of the GCMV 5' NCR can be nullified by an attenuating effect of either the GCMV CP or 3' NCR.

\section{DISCUSSION}

We report here that a recombinant PVX containing the $5^{\prime}$ NCR of GCMV RNA-2 induced severe necrotic symptoms on three Nicotiana spp. displaying only chlorotic mosaic when infected with wild-type PVX. The GCMV $5^{\prime}$ NCR in itself must be responsible for the necrotic reactions observed because (i) several independently constructed PVX vectors that contained this region (PVX:5'NCR, PVX:5'NCR $\Delta$, and a spontaneous deletion mutant from PVX:5'CPGC3') displayed the same phenotype while the presence of a foreign sequence usually attenuated the symptoms induced by PVX (Chapman et al. 1992; Hammond-Kosack et al. 1995; this study), (ii) Northern blot analysis showed that the necrotic symptoms were not associated with an increase in PVX replication, and (iii) the depressed accumulation of PVX:5 $5^{\prime} \mathrm{NCR}$ cannot be responsible for the necrotic reaction either since it was also observed with PVX:spacer, a virus that does not induce necrosis. It is also important to note that no initiation codon was introduced when cloning the foreign sequences in $\mathrm{pP} 2 \mathrm{C} 2 \mathrm{~S}$, dismissing translation initiation from within the inserted sequences as having an effect on the phenotype.

Symptoms observed on plants infected with PVX:5'NCR $\Delta$, compared with those induced by PVX: $5^{\prime} \mathrm{NCR}$, suggest that the three conserved GCMV stem loops deleted in this construction are not directly responsible for the necrotic response. However, the somewhat lower necrogenic potential of PVX: $5^{\prime} \mathrm{NCR} \Delta$ indicates that the stem loops may influence the development of necrosis, either by interfering with some host or environmental factors, or by stabilizing some essential structure within the GCMV 5' NCR.

Because the presence of the first 70 nucleotides of GCMV $5^{\prime} \mathrm{NCR}$ is necessary (PVX:5'NCR $\Delta 70$ does not induce necrosis) but not sufficient (PVX:5'NCR70 does not induce necrosis either), no conclusion can be made as to the minimal sequence required to trigger the necrotic response. However, several hypotheses can be put forward: (i) the minimal sequence required covers the entire region (first 159 nucleotides) present in PVX:5'NCR $\Delta$; (ii) the sequence required is composed of a smaller domain but one that spans the $5^{\prime} \mathrm{NCR}$ $\triangle 70$ and $5^{\prime}$ NCR70 regions; or (iii) several domains scattered along the $5^{\prime} \mathrm{NCR}$ are necessary to efficiently trigger necrosis. If so, those sequences could play different roles, some being directly responsible for the necrotic response, others being crucial to maintain some important structure.

Noncoding regions of other viruses have been shown to influence the symptoms expressed. The presence of additional nucleotides in the $3^{\prime} \mathrm{NCR}$ of tobacco vein mottling virus (TVMV) resulted in attenuated symptoms on $N$. tabacum plants, compared with wt TVMV, without reduced virus accumulation (Rodriguez-Cerezo et al. 1991). In AlMV, a 79nucleotide deletion in the leader sequence of RNA-3 changed the symptoms from undetectable to necrotic ringspots (van der Vossen et al. 1996). As was the case for AlMV virus, but unlike TVMV, the effect of the $5^{\prime}$ NCR of GCMV RNA-2 on symptom expression was masked by the presence of other viral sequences, since PVX:5'CPGC3' did not induce necrosis. Furthermore, little difference has been observed between $N$. benthamiana plants infected with PVX:5'CPGC3' and PVX: $\Omega$ CPGC3', showing that the $5^{\prime}$ NCR does not strongly influence the symptoms induced when in this genomic context. How- 
ever, the $5^{\prime} \mathrm{NCR}$ was again able to induce necrotic symptoms when both the GCMV $3^{\prime}$ NCR and most of the CP coding sequence were spontaneously deleted. Further experiments will be necessary to assess the influence of other GCMV or nonviral sequences on the ability of the $5^{\prime}$ NCR to induce necrosis, and to delineate these regulatory sequences.

The necrotic symptoms induced by GCMV 5' NCR did not reproduce the symptoms of GCMV-infected N. tabacum or $N$. benthamiana plants. As mentioned above, this may be because this sequence does not act as a dominant symptomatology determinant. Nepoviral symptomatology seems to be a complex phenomenon. Harrison et al. (1974) mapped the symptom determinants of raspberry ringspot virus on both RNA-1 and RNA-2, with either the latter acting in a supplementary manner or one RNA being epistatic on the other depending on the host plant. Similarly, investigations concerning barley stripe mosaic hordeivirus (Petty et al. 1994) showed that symptoms can result from complex interactions involving several components of the virus. Thus, it is not possible to conclude whether the GCMV 5' NCR is partially involved in GCMV symptom expression or not.
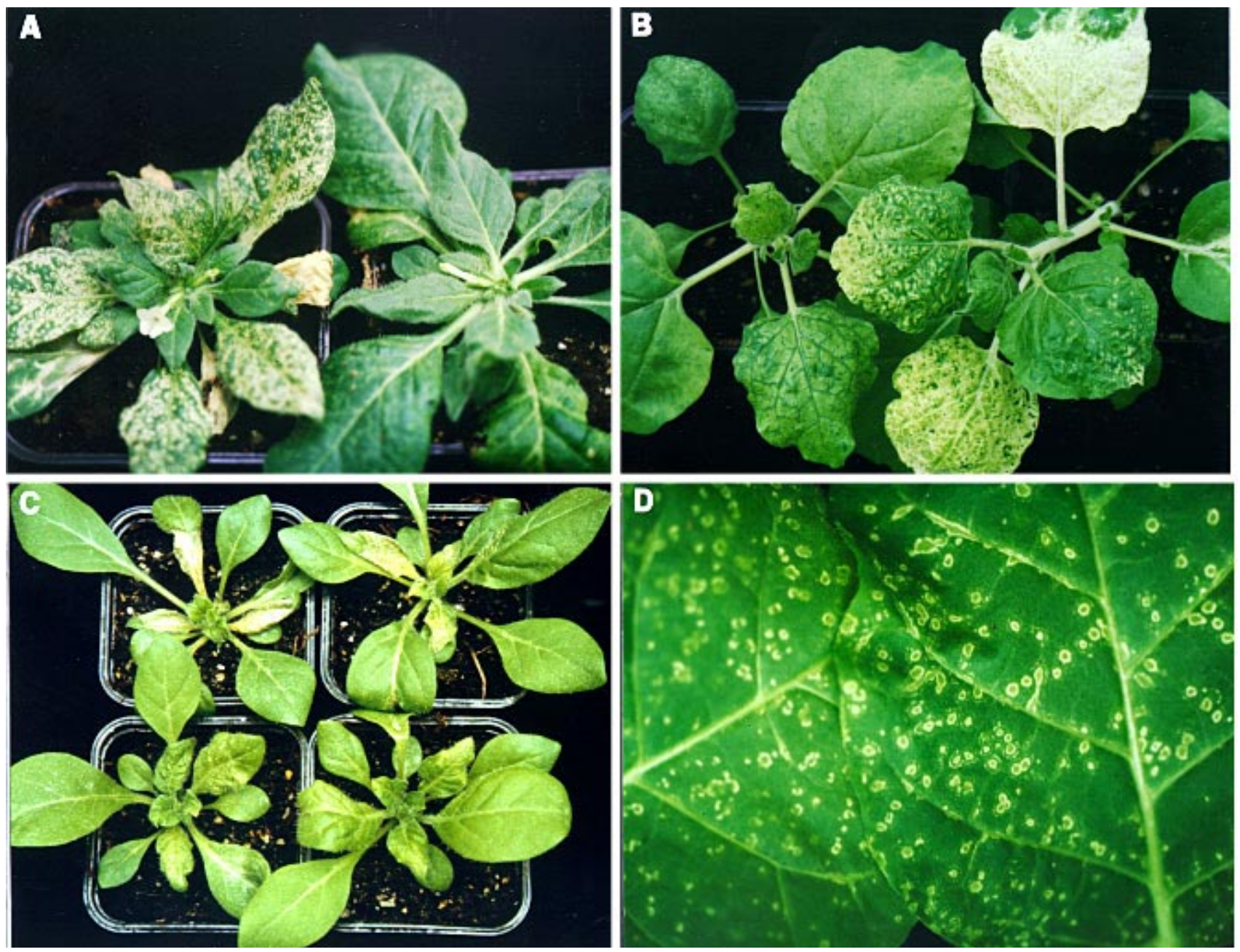

Fig. 3. Symptoms induced by the various recombinant potato virus X (PVX) on different Nicotiana spp. A, Nicotiana clevelandii plants infected with PVX (right) and PVX:5'NCR (left), 20 days post inoculation (dpi). B, $N$. benthamiana plants infected with PVX (left) and PVX:5'NCR (right), 15 dpi. The $N$. benthamiana plant infected with PVX:5'NCR presented does not show the necrotic symptoms but the bleaching we sometimes observed. C, Symptoms induced by PVX:5'NCR (top left), PVX:5'NCR $\Delta$ (top right), PVX:5'NCR $\Delta 70$ (bottom left), and PVX:5'NCR70 (bottom right) on $N$. clevelandii, 11 dpi. D, Symptoms induced by PVX:5'NCR (left) and PVX:5'CPGC3's (right) on N. tabacum apical leaves, 15 dpi. 


\section{MATERIALS AND METHODS}

\section{Construction of pP2C2S recombinants.}

The 5' NCR of GCMV RNA-2 was retrieved from pGC2, a pBluescribe (Stratagene, La Jolla, CA) containing a hybrid gene composed of GCMV 5' NCR, an AUG initiation codon, the sequence encoding the $\mathrm{CP}$ minus its first 134 nucleotides, and the 3' NCR of GCMV (Brault et al. 1989). The plasmid was digested with EcoRI and SalI and the 223-bp fragment excised, corresponding to the $5^{\prime} \mathrm{NCR}$, was blunted and inserted in the EcoRV site of pZero2-Kan vector (Invitrogen, Leek, The Netherlands). The resulting recombinant plasmid (pZero:5'NCR) was successively digested with PstI, made blunt ended with the Klenow fragment of E. coli DNA polymerase I, and cleaved with XhoI, allowing the cloning of the 5 ' NCR in pP2C2S (Rommens et al. 1995; Scholthof et al. 1995), digested previously with EcoRV and SalI, to produce pP2C2S:5'NCR.

The whole hybrid gene composed of GCMV $5^{\prime}$ NCR, an AUG initiating codon, GCMV CP, and $3^{\prime}$ NCR sequences was also cloned in $\mathrm{pP} 2 \mathrm{C} 2 \mathrm{~S}$. The 2-kbp fragment obtained after EcoRI digestion of plasmid pC19 containing this construct (Brault et al. 1989) was made blunt ended and ligated in
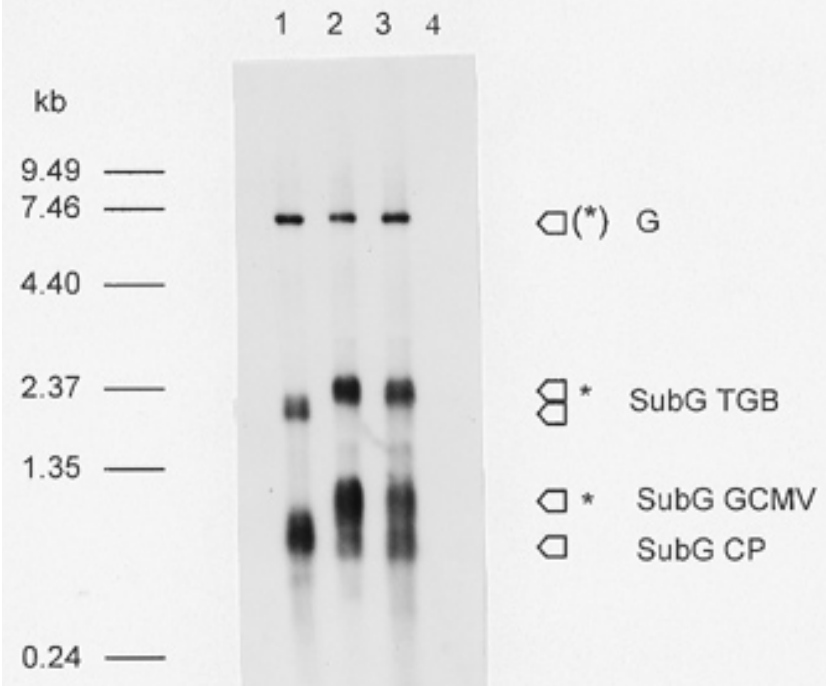

Fig. 4, Northern (RNA) blot hybridization analysis of Nicotiana clevelandii plants infected with potato virus $\mathrm{X}(\mathrm{PVX}), \mathrm{PVX}: 5^{\prime} \mathrm{NCR}$, or PVX:5'NCRA. Total RNA extractions were carried out 9 days post inoculation on systemically infected leaves. Lane 1: PVX infected (125 ng of total RNA); lane 2: PVX:5'NCR infected (1 $\mu \mathrm{g}$ of total RNA); lane 3: PVX:5'NCR $\Delta$ infected ( $1 \mu \mathrm{g}$ of total RNA); healthy plant ( $1 \mu \mathrm{g}$ of total RNA). Hybridization was performed with a probe specific for the PVX coat protein (CP) coding region. Presence of the grapevine chrome mosaic nepovirus (GCMV) 5' noncoding region (NCR) or $5^{\prime}$ NCR $\Delta$ in extracts from PVX:5'NCR or PVX:5'NCR $\Delta$ was checked by hybridization with a probe specific for the $5^{\prime}$ NCR of GCMV RNA-2 (data not shown). An eightfold lower amount of total RNAs was loaded in the wt PVX lane. RNA ladder is represented on left side. G: genomic viral RNA; SubG TGB: subgenomic RNA allowing expression of the triple gene block proteins of PVX; SubG GCMV: subgenomic RNA allowing expression of the GCMV sequences; SubG CP: subgenomic RNA of the PVX CP; asterisks show the RNAs that were positive when the hybridization with the probe specific for the GCMV 5' NCR was performed. Asterisk in parentheses indicates that the genomic RNAs were positive for samples in lane 2 and 3 only.
EcoRV-cut pZero2. The construct was then inserted into $\mathrm{pP} 2 \mathrm{C} 2 \mathrm{~S}$, following the same protocol as mentioned above, to produce the plasmid $\mathrm{pP} 2 \mathrm{C} 2 \mathrm{~S}: 5^{\prime} \mathrm{CPGC} 3^{\prime}$. To produce $\mathrm{pP} 2 \mathrm{C} 2 \mathrm{~S}$ : SCPGC3', the plasmid TCaps3 (Brault 1990; Brault et al. 1993) was digested with HindIII and EcoRI, and blunt ended with the Klenow fragment of E. coli DNA polymerase I. The 1.9-kbp fragment was inserted into pZero2 and then into pP2C2S following the same steps as described for the construction of pP2C2S:5'CPGC3'.

To obtain pP2C2S:5'NCR 470 , deletions were performed at the $5^{\prime}$ end of GCMV 5' NCR with the Erase-a-Base System kit (Promega, Madison, WI). Deleted fragments were gel purified and cloned in pP2C2S digested with EcoRV and SalI. The insert of one of the recombinant plasmids was sequenced, showing that the foreign sequence insert corresponded to the GCMV 5' NCR lacking its first 70 nucleotides.

The recombinants pP2C2S:loop and pP2C2S:5'NCR70 were obtained via cloning of hybridized oligonucleotides (Eurogentec, Seraing, Belgium). The oligonucleotides used to clone the stem loop only were loopP (5'-CGTTGGAAAATT ATTTCCAA-3') and loopM (5'-TCGATTGGAAATAATTTT CCAA-3') Those used to clone the first 70 nucleotides of GC MV 5' NCR were $5^{\prime} \mathrm{NC70P}$ (5'-CGTTGGAAA . . GCMV sequence ... TACTTTC-3') and 5'NC70M (5'-AGCTGAA AGTA . . . antisense GCMV sequence . . TTTCCAA- $3^{\prime}$ ). When hybridized, the oligonucleotides present cohesive ends compatible with ClaI and SalI ends. Annealing of complementary oligonucleotides was performed under the following conditions: $1 \mathrm{nmol}$ of each of the complementary oligonucleotides was boiled for $5 \mathrm{~min}$ in $20 \mathrm{mM}$ Tris- $\mathrm{HCl} \mathrm{pH} \mathrm{7.4,} 2$ $\mathrm{mM} \mathrm{MgCl}_{2}, 5 \mathrm{mM} \mathrm{NaCl}$. The reaction was allowed to cool down slowly to $30^{\circ} \mathrm{C}$. Ten picomoles of one pair of oligonucleotides was ligated into $\mathrm{pP} 2 \mathrm{C} 2 \mathrm{~S}$ digested with $C l a \mathrm{I}$ and SalI. The vector was previously polyethylene glycol (PEG) precipitated to avoid competition between the 14-bp ClaISalI fragment excised and the oligonucleotides. The recombinant plasmids were screened by restriction analysis and PCR, and eventually sequenced to check the presence of the foreign sequence.

Sequencing of plasmid DNA was performed with Sequenase Version 2.0 (US Biochemicals, Cleveland, $\mathrm{OH}$ ) and ${ }^{35} \mathrm{SdATP}-\alpha \mathrm{S}$ as described by the manufacturer. The primers used were PVX3' (5'-TAGGCCCTACCACTTGTC-3', in the antisense orientation from positions 5820 to 5837 of PVX) and PVX5' (5'-AAGGGCCATTGCCGATCT-3', in the sense orientation from positions 5585 to 5602 of PVX).

\section{In vitro transcriptions and plant inoculations.}

Plasmids were linearized with SpeI prior to transcription. Transcription reaction mixtures $(25 \mu \mathrm{l})$ contained $40 \mathrm{mM}$ Tris$\mathrm{HCl} \mathrm{pH} 8.0 ; 8 \mathrm{mM} \mathrm{MgCl} 2 ; 2 \mathrm{mM}$ spermidine; $25 \mathrm{mM} \mathrm{NaCl} ; 5$ $\mathrm{mM}$ dithiothreitol (DTT), 0.8 units of RNasin (Promega) per $\mu \mathrm{l} ; 2 \mathrm{mM}$ concentrations of ATP, CTP, and UTP; $0.2 \mathrm{mM}$ GTP, $0.5 \mathrm{mM}$ concentration of the cap analog $\mathrm{m}^{7} \mathrm{G}\left(5^{\prime}\right) \mathrm{ppp}\left(5^{\prime}\right) \mathrm{G}$ (Pharmacia, Uppsala, Sweden); $0.4 \mu \mathrm{g}$ of linearized DNA per $\mu \mathrm{l}$. Reactions were incubated at $37^{\circ} \mathrm{C}$ for 5 min before adding 4 units of T7 RNA polymerase (Gibco/BRL, Life Technologies, Gaithersburg, MD) per $\mu$ l. After $25 \mathrm{~min}$ at $37^{\circ} \mathrm{C}$, GTP was added to a final concentration of $2 \mathrm{mM}$. Following a further $40 \mathrm{~min}$ of incubation at $37^{\circ} \mathrm{C}$, the nucleic acids were deproteinized by phenol/chloroform 
extraction and ethanol precipitation. The transcripts were resuspended in $40 \mu \mathrm{l}$ of $10 \mathrm{mM}$ Tris- $\mathrm{HCl} \mathrm{pH}$ 7.5, $1 \mathrm{mM}$ EDTA, $1 \mu \mathrm{g}$ of bentonite per $\mu \mathrm{l}$, and $50 \mathrm{ng}$ of tRNA per $\mu \mathrm{l}$ and mechanically inoculated onto $N$. clevelandii or $N$. benthamiana leaves previously dusted with Carborundum. Plant extract inoculations were performed with infected leaves ground in 3 vol of $50 \mathrm{mM} \mathrm{Na} \mathrm{HPO}_{4}, 20 \mathrm{mM}$ sodium diethyldithiocarbamate (DIECA) added with activator charcoal.

\section{RNA extraction and Northern blot analysis.}

Total RNAs were extracted from $0.5 \mathrm{~g}$ of newly infected apical leaves according to Verwoerd et al. (1989). One microgram of total RNAs (150 ng for plants infected with nonrecombinant PVX) was run on a $1 \%$ agarose gel containing formaldehyde (Miller 1987), transferred to a Hybond- $\mathrm{N}^{+}$ membrane (Amersham, Rainham, UK), and hybridized with digoxigenin (DIG)-labeled riboprobes. Probe synthesis and purification, hybridization, and chemiluminescent revelation were conducted following the procedures recommended by the supplier (Boehringer, Mannheim, Germany).

The RNA probe complementary to the $3^{\prime}$ region of the PVX RNA was obtained by transcription of an EcoRV-linearized plasmid containing the $3^{\prime}$ terminal EcoRV-SstI fragment of $\mathrm{pP} 2 \mathrm{C} 2 \mathrm{~S}$. The RNA probe complementary to the $5^{\prime} \mathrm{NCR}$ of GCMV was obtained by transcription of XhoI-linearized pZero:5'NCR. Both probes were synthesized with T3 RNA polymerase in the presence of DIG-dUTP as the label.

\section{RT-PCR experiments.}

RT-PCR analyses were conducted in complement to Northern blot analysis to determine the presence and the size of inserts. Each sample consisted of a leaf disk about $1 \mathrm{~mm}$ in diameter, punched with the small end of a 1-ml micropipette tip. Samples were ground in $10 \mu \mathrm{l}$ of sterile water and centrifuged at $18,000 \times g$ for $2 \mathrm{~min}$. RT-PCRs were performed with $1 \mu \mathrm{l}$ of supernatant in a $50-\mu$ reaction containing $0.3 \%$ (wt/vol) Triton-X100; $10 \mathrm{mM}$ Tris- $\mathrm{HCl} \mathrm{pH} 8.0 ; 1.5 \mathrm{mM} \mathrm{MgCl}_{2} ; 50 \mathrm{mM}$ $\mathrm{KCl} ; 250 \mu \mathrm{M}$ concentrations of dATP, dCTP, dGTP, and dTTP; $0.5 \mu \mathrm{M}$ concentration of each primer; 1 unit of ExtraPol (Eurobio, Les Ullis, France), and 0.5 unit of AMV RTase (US Biochemicals). The following temperature profile was programmed: $25 \mathrm{~min}$ at $42^{\circ} \mathrm{C}$ followed by 40 cycles of 20 $\mathrm{s}$ at $92^{\circ} \mathrm{C}, 20 \mathrm{~s}$ at $50^{\circ} \mathrm{C}$, and $40 \mathrm{~s}$ at $72^{\circ} \mathrm{C}$. The primers used were PVX $5^{\prime}$ or PVX5'2: (5'-ACTGGGGAATCAATCACAG$3^{\prime}$, in the sense orientation from positions 5535 to 5553 of PVX) and PVX3'.

\section{ACKNOWLEDGMENTS}

We are grateful to D. C. Baulcombe for kindly providing the plasmid $\mathrm{pP} 2 \mathrm{C} 2 \mathrm{~S}$ and advice concerning its manipulation. We thank $\mathrm{X}$. Capdevielle and M. Martin for growing and taking care of the plants in the greenhouse. We thank K. Mayo for English reviewing. I. Fernandez is supported by the French Ministry of Higher Education and Research.

\section{LITERATURE CITED}

Brault, V. 1990. Isolement et caractérisation du gène de la protéine capsidique du virus de la mosaïque chromée de la vigne (GCMV): expression in vitro et dans des plantes transgéniques. Ph.D. thesis. University of Bordeaux, Bordeaux, France.

Brault, V., Candresse, T., Le Gall, O., Delbos, R.-P., Lanneau, M., and
Dunez, J. 1993. Genetically engineered resistance against grapevine chrome mosaic nepovirus. Plant Mol. Biol. 21:89-97.

Brault, V., Hibrand, L., Candresse, T., Le Gall, O., and Dunez, J. 1989. Nucleotide sequence and genetic organization of Hungarian grapevine chrome mosaic nepovirus RNA2. Nucleic Acids Res. 17:7809-7819.

Calder, V. L., and Palukaitis, P. 1992. Nucleotide sequence analysis of the movement genes of resistance breaking strains of tomato mosaic virus. J. Gen. Virol. 73:165-168.

Chapman, S., Kavanagh, T., and Baulcombe D. 1992. Potato virus X as a vector for gene expression in plants. Plant J. 2:549-557.

Culver, J. N. 1996. Tobamovirus cross protection using a potexvirus vector. Virology 226:228-235.

Culver, J. N., Lindbeck A. G. C., and Dawson, W. O. 1991. Virus-host interactions: Induction of chlorotic and necrotic responses in plants by tobamoviruses. Annu. Rev. Phytopathol. 29:193-217.

Demangeat, G., Hemmer, O., Fritsch, C., Le Gall, O., and Candresse T. 1991. In vitro processing of the RNA2 encoded polyprotein of two nepoviruses: Tomato black ring virus and grapevine chrome mosaic virus. J. Gen. Virol. 72:247-252.

Goldbach, R., Martelli, G. P., and Milne, R. G. 1995. Family Comoviridae. Pages 341-347 in: Virus Taxonomy-Classification and Nomenclature of Viruses: Sixth Report of the International Committee on Taxonomy of Viruses. F. A. Murphy, C. M. Fauquet, D. H. L. Bishop, S. A. Ghabrial, A. W. Jarvis, G. P. Martelli, M. A. Mayo, and M. D. Summers, eds. Springer-Verlag, Vienna.

Hammond-Kosack, K. E., Staskawicz, B. J., Jones, J. D. G., and Baulcombe D. C. 1995. Functional expression of fungal avirulence gene from a modified potato virus $\mathrm{X}$ genome. Mol. Plant-Microbe Interact. 8:181-185.

Harrison, B. D., Murant, A. F., Mayo, M. A., and Roberts, I. M. 1974. Distributions of determinants for symptom production, host range and nematode transmissibility between the two RNA components of raspberry ringspot virus. J. Gen. Virol. 22:233.

Joosten, M. H. A. J., Vogelsang, R., Cozijnsen, T. J., Verberne, M., and de Wit, P. J. G. M. 1997. The biotrophic fungus Cladosporium fulvum circumvents $C f$-4-mediated resistance by producing unstable AVR4 elicitors. Plant Cell 9:367-379.

Jupin, I., Guilley, H., Richards K. E., and Jonard, G. 1992. Two proteins encoded by beet necrotic yellow vein virus influence symptom phenotype on leaves. EMBO J. 11:479-488.

Kavanagh, T., Goulden, M., Santa Cruz, S., Chapman, S., Barker, I., and Baulcombe, D. 1992. Molecular analysis of a resistance-breaking strain of potato virus X. Virology 189:609-617.

Kim, C.-H., and Palukaitis, P. 1997. The plant defense response to cucumber mosaic virus in cowpea is elicited by the viral polymerase gene and affects virus accumulation in single cells. EMBO J. 16: 4060-4068.

Le Gall, O., Candresse, T., and Dunez, J. 1995a. Transfer of the $3^{\prime}$ nontranslated region of grapevine chrome mosaic virus RNA-1 by recombination to tomato black ring virus RNA-2 in pseudorecombinant isolates. J. Gen. Virol. 76:1285-1299.

Le Gall, O., Lanneau, M., Candresse, T., and Dunez, J. 1995b. The nucleotide sequence of the RNA-2 of an isolate of the English serotype of tomato black ring virus: RNA recombination in the history of nepoviruses. J. Gen. Virol. 76:1279-1283.

Martelli, G. P., Lehoczky, J., and Quacquarelli, A. 1965. Proc. Int. Conf. Virus Vector Peren. Hosts, Univ. Calif. Agric. Sci., Davis, 389.

Martelli, G. P., and Quacquarelli, A. 1972. Grapevine chrome mosaic virus. No. 103 in: Descriptions of Plant Viruses. A. F. Murant and B. D. Harrison, eds. C.M.I./A.A.B., Old Woking, England.

Mayo, M. A., Barker, H., and Harrison, B. D. 1979. Polyadenylate in the RNA of five nepoviruses. J. Gen. Virol. 43:603-610.

Mayo, M. A., Barker, H., and Harrison, B. D. 1982. Specificity and properties of genome-linked proteins of nepovirus. J. Gen. Virol. 59: 149-162.

Mayo, M. A., and Martelli, G. P. 1993. New families and genera of plant viruses. Arch. Virol. 133:496.

Meshi, T., Motoyoshi, F., Maeda, T., Yoshiwoka, S., Watanabe, H., and Okada, Y. 1989. Mutations in the tobacco mosaic virus $30-\mathrm{kD}$ protein gene overcome Tm-2 resistance in tomato. Plant Cell 1:515-522.

Miller, K. 1987. Gel electrophoresis of RNA. Focus 9:14-15.

Neeleman, L., van der Kuyl, A., and Bol, J. F. 1991. Role of alfalfa mosaic virus coat protein gene in symptom formation. Virology 181:687693. 
Padgett, H. S., and Beachy R. N. 1993. Analysis of a tobacco mosaic virus strain capable of overcoming $N$ gene-mediated resistance. Plant Cell 5:577-586.

Petty, I. T. D., Donald, R. G. K., and Jackson, A. O. 1994. Multiple genetic determinants of barley stripe mosaic virus influence lesion phenotype on Chenopodium amaranticolor. Virology 198:218-226.

Preiss, T., and Hentze, M. W. 1998. Dual function of the messenger RNA cap structure in poly(A)-tail-promoted translation in yeast. Nature 392:516-520.

Rodriguez-Cerezo, E., Klein, P. G., and Shaw, J. G. 1991. A determinant of disease symptom severity is located in the 3'-terminal noncoding region of the RNA of a plant virus. Proc. Natl. Acad. Sci. USA 88: 9863-9867.

Rommens, C. M. T., Salmeron, J. M., Baulcombe, D. C., and Staskawicz, B. J. 1995. Use of a gene expression system based on potato virus $\mathrm{X}$ to rapidly identify and characterize a tomato Pto homolog that controls fenthion sensitivity. Plant Cell 7:249-257.

Saito, T., Meshi, T., Takamatsu, N., and Okada, Y. 1987. Coat protein gene sequence of tobacco mosaic virus encodes a host response determinant. Proc. Natl. Acad. Sci. USA 84:6074-6077.
Santa Cruz, S., and Baulcombe, D. C. 1993. Molecular analysis of potato virus $\mathrm{X}$ isolates in relation to the potato hypersensitivity gene $N x$. Mol. Plant-Microbe Interact. 6:707-714.

Schoelz, J., Shepherd, R. J., and Daubert, S. 1986. Region VI of cauliflower mosaic virus encodes a host range determinant. Mol. Cell. Biol. 6:2632-2637.

Scholthof, H. B., Scholthof, K.-B. G., and Jackson, A. O. 1995. Identification of tomato bushy stunt virus host-specific symptom determinants by expression of individual genes from potato virus $\mathrm{X}$ vector. Plant Cell 7:1157-1172.

van der Vossen, E. A. G., Neeleman, L., and Bol, J. F. 1996. The $5^{\prime}$ terminal sequence of alfalfa mosaic virus RNA3 is dispensable for replication and contains a determinant for symptom formation. Virology 221:271-280.

Verwoerd, T. C., Dekker, B. M. M., and Hoekema, A. 1989. A smallscale procedure for the rapid isolation of plant RNAs. Nucleic Acids Res. 17:2362.

Zhang, L., Hanada, K., and Palukaitis P. 1994. Mapping local and systemic symptom determinants of cucumber mosaic virus in tobacco. J. Gen. Virol. 75:3185-3191. 